УДК: 340.13:342.56(477)

DOI https://doi.org/10.32837/yuv.v0i4.2225

\author{
Л. Удовика, \\ доктор юридичних наук, професор, \\ завідувач кафедри історії і теорії держави та права \\ Запорізького національного університету

\section{В. Новоселова,} \\ кандидат юридичних наук, \\ головний спеціаліст відділу обліку звернень громадян та діловодства \\ Запорізького апеляційного суду
}

\title{
ПРИРОДА І ЗМІСТ ДОВІРИ ДО СУДОВОЇ ВЛАДИ В УКРАЇНІ КРІЗЬ ПРИЗМУ СВІТОВОГО ДОСВІДУ
}

Сучасний світовий досвід переконливо свідчить, що довіра суспільства до судової влади «вплетена» в механізм функціонування державної влади, а в кризові періоди державного й суспільного розвитку виходить на перший план, стає показником, критерієм оцінки іï діяльності i, водночас, атрибутом поступального правового розвитку країни. Низький рівень суспільної довіри до судової влади ускладнює механізм правового захисту, виконання судових рішень, забезпечення правосуддя, унеможливлює входження до європейського правового простору, задекларованого у Преамбулі Конституції України.

В умовах поширення пандеміі COVID-19 суспільна довіра до державної влади загалом і судової влади зокрема набуває особливого значення. «У принципово нових умовах судова влада покликана забезпечувати правосуддя, баланс інтересів суспільства й людини, громадської безпеки і права на справедливий суд» [1, p. 68]. До уваги потрібно взяти й те, що «в найближчій перспективі перед національними й міжнародними судовими інститутами, поряд із зазначеними, постануть нові виклики й загрози, серед них, зокрема, такі, як значне зростання навантаження на суди у зв'язку з економічною кризою, порушенням соціальних, еко- номічних, політичних, культурних прав громадян; необхідність оперативного організаційного реагування на нові виклики; обмеження фінансових і матеріальних ресурсів та переосмислення стратегій фінансування» [1, p. 68].

Упродовж останніх років науковці, вітчизняні й міжнародні експерти, громадяни та інститути громадянського суспільства акцентують увагу на критично низькому рівні довіри до судової влади в Україні. Проблеми із суспільною довірою визнають і органи судової влади та судді. Результати численних соціологічних досліджень також підтверджують низький рівень довіри до органів державної влади загалом і судової влади зокрема. Згідно 3 оприлюдненим дослідженням, проведеним соціологічною службою Центру Разумкова «Довіра до інститутів суспільства та політиків, електоральні орієнтаціï громадян України (липень-серпень 2021р.)» відомості про баланс довіри / недовіри до соціальних інституцій (різниця між часткою тих, хто довіряє, і тих, хто не довіряє суспільному інституту) такі: суди (судова система загалом) - мінус 58,7\% (зовсім не довіряю: 41,1\%), місцевий суд - мінус 44,9\% (зовсім не довіряю: $34,7 \%$ ); Верховний Суд - мінус $41,7 \%$ (зовсім не довіряю: $34,8 \%$ ), 
Конституційний суд України - мінус $41,9 \%$ (зовсім не довіряю: $35,2 \%$ ), Вищий антикорупційний суд - мінус $52,8 \%$ (зовсім не довіряю: $39,8 \%$ ). Слід зауважити, що проблеми із суспільною довірою притаманні й іншим органам української держави: Національне антикорупційне бюро України - мінус 54,4\% (зовсім не довіряю: $40,4 \%)$, Спеціалізована антикорупційна прокуратура - мінус 55,7\% (зовсім не довіряю: 40,0\%), Національне агентство з питань запобігання корупції - мінус $56,4 \%$ (зовсім не довіряю: 41,4\%). Далі ми наведемо результати соціологічного опитування про довіру до інших гілок влади: Верховна Рада України - мінус $56,4 \%$ (зовсім на довіряю: $34,6 \%$ ); Президент України - мінус 21,4\% (зовсім не довіряю: 28,7\%); Кабінет Міністрів України - мінус 50,5\% (зовсім не довіряю: $35,1 \%$ ) [2].

Ми поділяємо думку науковців про те, що «справжнє ставлення громадян України до судової системи неможливо просто проаналізувати або представити у вигляді лише одного статистичного показника. Така оцінка повинна грунтуватися на комплексному підході, який також ураховує національні особливості судової влади; ступінь залучення громадян до цієї сфери; поширювану негативну інформацію, у межах якої діють національні суди» [3]. Зазначене вимагає нового підходу до розуміння довіри до судової влади, її природи, джерел, напрямів відновлення і підтримання. Лише за умови 3'ясування іiі глибинної природи, змісту, форм, чинників формування, розмежування і співставлення видів, визначення кола суб'єктів, які закладають підгрунтя довіри до неї, стає можливим обгрунтування напрямів і засобів відновлення довіри до судової влади в Україні в контексті утвердження принципу верховенства права.

Мета статті - визначення природи та змісту довіри до судової влади в контексті світового досвіду як під- грунтя відновлення довіри до судової влади в Україні.

Методологічним підгрунтям дослідження є науковий доробок вітчизняних і зарубіжних науковців, який умовно можна поділити на дві групи: перша група представлена працями науковців, які досліджували загальнотеоретичні аспекти верховенства права, правосуддя, довіри до державних органів, впливу інститутів громадянського суспільства на судову владу, правову культуру, правову свідомість (В. Петришин, В. Лемак, Н. Оніщенко, Ю. Битяк, С. Бобровник, С. Бігун, В. Борденюк, Д. Гудима, С. Гусарєв, О. Данильян, Д. Єрмоленко, А. Заєць, В. Завальнюк, Ю. Калиновський, Б. Ковальчук, В. Колодій, В. Колісник, Л. Луць, С. Максимов, Ю. Оборотов, С. Погребняк, П. Рабінович, О. Тодика, О. Тихомиров, Л. Удовика, І. Яковюк та інші); друга група охоплює здобутки науковців, які досліджували проблеми судової влади, зокрема аспекти довіри до судової влади (В. Бринцев, В. Городовенко, С. Головатий, А. Демічев, В. Долежан, С. Іваницький, А.Крусян, І. Марочкін, Л. Москвич, I. Назаров, О. Овчаренко, Я. Романюк, I. Русанова, О. Святоцький, С. Шевчук, Н. Шукліна, Б. Футей, Г. Веллінг, Дж. Лебел, У. Ледерман, П. Лільєквист, Дж. В. Робертс, Дж. Т. Дж. Сенюк, Л. Таль та інші).

Першочерговим у виконанні зазначених дослідницьких завдань є з'ясування природи і змісту довіри до судової влади. Під «змістом» розуміють усе, що міститься в системі. Сюди входять не лише елементи, але й відносини, зв'язки, процеси, тенденції розвитку, всі частини системи. Під «формою» розуміють спосіб зовнішнього вираження змісту, зовнішню конфігурацію. Форма є також способом існування матерії. Під «формою» розуміють також внутрішню організацію, спосіб зв'язків елементів у системі [4, с. 394]. Форма є змістовною, а зміст - оформленим. 
Філософське тлумачення «змісту» i «форми» та їхнього зв'язку є засадничим у дослідженні змісту і форм довіри до судової влади. Грунтуючись на філософських категоріях «змісту» i «форми», тлумаченні феномену довіри до державної влади в сучасних соціогуманітарних і юридичних науках, різновидом якої є довіра до судової влади, та на основі дослідження історичного й сучасного досвіду поширення довіри до судової влади, слід визначити їі зміст і форму.

По-перше, довіра до судової влади як комплексне явище має соціальну природу, яка втілюється у соціальний складник. Ставлення до судової влади (відповідно й довіра до судової влади) відображає насамперед ставлення судової влади (як однієї із гілок державної влади) до судової системи та суб'єктів судової влади, в кінцевому підсумку - ставлення до права та законів загалом. Судова система й судова влада $€$ втіленням самого права. Оскільки право як регулятивна система перебуває в одному ряду з іншими соціальними регуляторами (звичаями, традиціями, мораллю, релігією), засади судової влади як публічної і державної влади грунтуються на соціальних нормах та соціальних очікуваннях. Соціальне регулювання - «це комплекс впливів, об’єднаних спільною метою, методами, більш-менш раціоналізованою програмою досягнення порядку в якійсь точці чи секторі реальності» [5, с. 9]. Саме тому «далеко не завжди причини невдалого правового регулювання знаходяться в самому праві, так само, як і його регулятивний успіх не належить винятково йому самому» [5, с. 769]. У цьому сенсі ефективність правового регулювання як ставлення судової влади значною мірою залежить від його зв'язку з іншими соціальними регуляторами.

Принципово важливою вимогою до судової влади як соціально-правового інституту $€$ вимога відповідати історично встановленим, панівним, апріорним уявленням, поняттям і принципам. Такі уявлення і поняття історично зумовлені, трансформуючись під час історичного розвитку, проте будь-яка система, що виникає, неодмінно потребує їх в якості своєї основи, свого підгрунтя. Саме відповідність судової системи та судової влади уявленням про справедливе, правдиве, виправдане, принципово значуще, що підтримується більшістю, є ознакою ї легітимності та визначає їхню соціальну природу. У цьому сенсі важливо, щоб судова влада як одна 3 гілок державної влади відповідала всім вимогам, які висуваються суспільством до державної влади і, водночас, зберігала свої особливі риси - передусім незалежність і самостійність. Легітимність як вимога до соціальних інститутів загалом і судової влади зокрема випливає з проблем співвідношення права i справедливості, права та розуму, права та совісті, права й моралі, тобто проблем, що постійно виникають. Ці проблеми знімаються, якщо $€$ правосуддя. Послаблення і втрата легітимності призводять до соціальної дезорганізації і розпаду державних структур, а втрата довіри до судової влади підриває іï авторитет.

Соціальний складник довіри до судової влади втілюється як на рівні багатофакторного соціального регулювання (інтереси, установки, бажання, прогнози), який $є$ первинним, попереднім, так і на рівні соціального нормативного регулювання (моральні, релігійні, політичні), який $€$ раціональним способом організації і впорядкування суспільних відносин. Соціальна природа довіри до судової влади виявляється і в тому, що, попри економічні, політичні, соціальні, культурні та інші відмінності, будь-яка особа виявляє та висловлює своє ставлення до судової влади на основі того, як вона сприймає й оцінює ii діяльність, наскільки захищеною відчуває себе та наскільки судова влада, на думку цієї особи, втілює 
правосуддя. Саме тому вкрай важливо, щоб судова система та судова влада діяли в інтересах людей, а іi рішення були зрозумілими. Судова влада не лише розв'язує питання, що мають фундаментальне значення для суспільства загалом, але й впливає своїми рішеннями та ухвалами на життя, звичайні справи окремих людей, які шукають допомоги та захисту в судах. Як слушно зауважує А. Яковлєв, саме «судова система той найважливіший соціальний інститут права, під час діяльності якого державі протягом судового процесу на рівних протистоять фізичні особи та юридичні особи; водночас учасники процесу рівні перед законом, унаслідок чого владний примус виступає у формі судового рішення. За критерієм місця, ролі, ступеня ефективності діяльності судової системи, рівня іï авторитету в загальній низці соціальних інститутів, які забезпечують стабільність суспільних відносин, відрізняються між собою поліцейські та демократичні держави» [6, с. 145].

Для розуміння соціальної природи довіри до судової влади до уваги слід брати антропологічний підхід, згідно з яким довіра тісно пов'язана з людською гідністю і прагненням людини до того, щоб із ії ставленням та оцінкою рахувалися. Як зазначає Ф. Фукуяма, людина постійно вимагає від інших визнання своєї гідності або як особистості, або як члена релігійної, етнічної, расової чи іншої групи, і боротьба за таке визнання має неекономічне підгрунтя. «У минулі часи правителі вимагали від інших визнання своєї вищої цінності як царя, імператора чи пана. Нині люди прагнуть утвердити свій рівний статус як члена раніше не досить поважаних або принижених груп - жінок, геїв, українців, інвалідів, американських індіанців і так далі» [7, с. 212]. Саме «рівне визнання» - це мінімальна повага до якості людини, котра залишається після «стирання» випадкових і несуттєвих рис особистості (кольору шкіри, зовнішнього вигляду, соціального класу, віку, статі, культурного багажу, природних талантів тощо); це повага до антропної гідності або, за термінологією Ф. Фукуями, до «фактору ікс», який становить сутність людини. Враховуючи той факт, що судова влада є незалежною, висловити оцінку та вплинути на іï діяльність можна лише опосередковано, шляхом виявлення довіри чи недовіри. У цьому сенсі довіра до судової влади виступає лакмусовим папірцем іï діяльності, показником того, як суспільство оцінює і ставиться до судової влади.

Соціальний складник довіри до судової влади існує в різних проявах, одним із яких є правило «соціальної спрямованості». Згідно з цим правилом законодавчий акт повинен бути інтерпретований із позицій його більшої соціальної орієнтації судом. Сліди цього правила помітні в англійській справі Гейдона (Heydon's Case) 1564 р., воно вживалося Верховним Судом Сполучених Штатів у відомій справі Свята церква Трініті проти CШA (Holy Triniti Church v. United States) [8, с. 61]. Звернення суду у тлумаченні законодавчого акту до соціальної спрямованості цього правила навіть тоді, коли воно вступає в конфлікт із правилом «ясного значення», відображає укоріненість правосуддя в соціальності і, безумовно, сприяє збереженню і підвищенню довіри до судової влади з боку суспільства. Соціальний складник полягає і в тому, що довіра до судової влади є певною сукупною якістю, соціально-правовим капіталом, який відображає суму спільних правових цінностей, існуючих у суспільстві, а також здатність людей дотримуватися рішень (ухвал, вироків) судової влади, виконувати їх задля досягнення справедливості, правосуддя. Водночас суспільство очікує, що судова влада не лише в нинішньому, але й у майбутньому забезпечуватиме правосуддя. Довіра до судової влади прямо 
пов'язана 3 можливістю передбачити дії судової влади в майбутньому.

По-друге, довіра до судової влади характеризується етичним складником. Поняття «довіра до судововї влади» фіксує особливий етичний бік державно-владних відносин. Специфіка цих відносин полягає в тому, що вони грунтуються на етичному кредиті, добровільних взаємних зобов'язаннях, що виникають як результат вимог суспільства до судової влади загалом і суддів зокрема, а також $є$ підгрунтям довіри до судової влади. Етичні відносини між судовою владою i громадськістю грунтуються на переконаності останніх у доброчесності, вірності, відповідальності, чесності, правдивості, переконаності в такій діяльності органів судової влади та суддів, яка забезпечує досягнення правосуддя. В такому випадку легітимність $€$ оціночною категорією, що наповнюється змістом за результатами здійснення і реалізаціі діяльності іï органів. Довіра до судової влади базується на сприйнятті й оцінці суддівської діяльності, їхніх рішень і дій, але не зводиться до ставлення громадян до інститутів судової влади. Довіра до судової влади, як і до будь-яких інших соціальних інститутів, містить передусім очікування громадян щодо їхніх рішень і дій цього інституту в майбутньому, а не тільки в минулому. Йдеться про певний кредит довіри - очікування більш позитивних дій і правосудних рішень у майбутньому порівняно 3 тими, котрі, на думку громадян, зроблені в минулому. Крім того, довіра до судової влади має подвійний характер: $з$ одного боку, в іï основі знаходяться моральні засади співробітництва, коли майбутня діяльність судової влади авансовано отримує характеристики, що відповідають очікуванням, а з іншого - іï виникнення зумовлене знаннями про судову владу та репутацію судів і суддів.

Довіра до судової влади значною мірою визначається цивілізаційними, культурними, історичними особливостями. Довіра до судової влади, як і довіра до державної влади та іiі інститутів, укорінені в кожній культурі як сукупність звичаїв, традицій, ритуалів, символів, норм і правил поведінки, певного стилю життя. Йдеться не лише про відмінні особливості довіри до судової влади в різних країнах, але й у різних культурах в межах однієї країни. Саме тому в одних країнах судова влада сприймається як втілення правосуддя, іi поважають, шанують, а в інших - ій не довіряють, намагаються за допомогою позасудових засобів розв'язувати правові конфлікти або ж звертатися до позадержавних судових інстанцій, які допускаються державою.

Культурний складник довіри тісно пов'язаний із історією. В контексті зазначеного уваги заслуговує приклад, наведений В. Бернхемом: «Закон про громадянські права 1964 р. було інтерпретовано у справі Об’єднання сталеливарників Америки проти Вебера (United Steelworkers of America v. Weber) таким чином, щоб дозволити засноване на різних расових належностях поводження 3 білими працівниками в ім'я виконання програми допомоги національним меншинам, хоча цей законодавчий акт забороняв дискримінацію «за ...pасою». Звернення до законодавчої історії дозволило розкрити мотиви такого рішення. Все це робилося задля виправдання «очевидного расового перекосу серед традиційно сегрегованих категорій» найманих робітників. У разі звернення до історії законодавчого акта встановлюється ціннісна ієрархія різних іiі етапів» [8, с. 60].

Дослідники довіри до судової влади та міжнародні експерти звертають увагу на те, що «існують суспільства, де державні інституції користуються високим рівнем довіри (здебільшого це країни сталої демократії, розташовані на півночі Європи), та суспільства з низькою довірою до державних інституцій (пострадянські країни). 
Можливі різні пояснення цьому феномену: вплив історії і геополітики, політичного режиму, соціальних потрясінь, релігії, рівня загальної довіри між людьми, добробуту тощо» [9]. Йдеться про те, що на рівень довіри до державних інститутів загалом і судових зокрема впливає низка чинників, як-от культурно-історичні та політичні.

У контексті зазначеного вище особливої уваги заслуговує питання довіри до судової влади у країнах із державним судовим плюралізмом та «позадержавним судовим плюралізмом, який допускається державою й охоплює правосуддя первинних груп (нуклеарна сім' я, групи молоді, що не порушують закон, а підпорядковуються своїм лідерам); дисциплінарну юстицію груп, асоціацій (політичних партій, профспілок, благодійних організацій тощо); юстицію бюрократичних організацій, які використовують моральні санкції, гласність процедур, остракізм тощо [10, с. 278]. В окремих випадках (наприклад, у міських культурних та етнічних общинах) держава прихильно ставиться до такого правосуддя, якщо воно $є$ більш ефективним та розвантажує державну судову систему. Слід зауважити, що окремі аспекти зазначеної проблематики досліджувалися в межах юридичної антропології, а також соціальної (культурної) антропології та можуть бути предметом окремого наукового дослідження.

По-третє, довіра до судової влади має психологічний складник. Згідно 3 положеннями, обгрунтованими в сучасній психології та філософіі, психічна компонента переважно охоплює сферу особистісних, суб'єктивно-психологічних переживань, спогадів, передчуттів із приводу ситуацій і подій, з якими особа стикалася чи може зіткнутися. Сюди відносять такі психологічні стани: 1) інстинктивно-афективні стани (нечіткі переживання, передчуття, стреси тощо); 2) емоції (гнів, страх, радість тощо);
3) почуття, що відрізняються більшим усвідомленням і наявністю образно-візуальних складників (симпатія, прихильність, антипатія, ненависть, тощо) [4, с. 158]. До сфери психіки належать також мотиви, мотиваційні механізми, воля, навички, які щодо судової влади виявляють себе як вчинки чи діі. У своїй сукупності, складній взаємозалежності зазначені стани, почуття, емоції, мотиви формують психічні регулятори поведінки. Такий аспект довіри пов'язаний як із минулим, так і з майбутнім. Зокрема П. Штомпка, визначаючи довіру як ставку стосовно майбутніх непередбачуваних дій інших, визначає три типи орієнтацій індивіда стосовно дій інших: 1) надія-розчарування; 2) віра-сумнів, для яких характерними є пасивність, спостережливість, дистанціювання, намагання уникнути будь-яких зобов'язань; 3) довіра, яка виявляється в ситуаціях, коли всупереч невизначеності та ризику особа все ж таки діє [Цит за: 11, с. 11-12]. У цьому сенсі в довіру до судової влади імпліцитно вплетені переживання, емоції, почуття, частина яких $є$ усвідомленою.

Психічний складник довіри до судової влади формується на рівні світовідчуття і світосприйняття, частково світорозуміння та на основі життєвого досвіду. Якщо в життевому досвіді людини наявні випадки (ситуаціi) звернення до судових органів, то залежно від судового рішення чи вироку ставлення особи до судової влади буде відповідним (позитивним / негативним). Окрім того, необхідно враховувати, що довіра до судової влади відображає установку-відношення особи до себе і до світу загалом. Як слушно зазначає T. Скрипкіна: «1) довіра $є$ форма віри, яка в соціально-психологічному плані $є$ самостійним видом установки-відношення до світу i до себе, сутність якої представлена співвідношенням міри довіри до світу та міри довіри до себе; основними умовами 
виникнення довіри є актуальна значущість об’єкта довіри та оцінка його як безпечного; 2) довіра - єдиний феномен, який в найбільш узагальненому вигляді має спільні формально-динамічні характеристики, умови виникнення, закономірності генези та функціонування; 3) основними формально-динамічними характеристиками довіри як відносно самостійного соціально-психологічного явища € міра, вибірковість і парціальність; 4) довіра до різних сторін світу й довіра до себе не існують ізольовано одна від одної і є відносно самостійними формами довіри. Рівень довіри до світу й довіри до себе знаходяться у стані рухомої рівноваги» [12]. Йдеться про те, що коли особа не довіряє собі, своїй поведінці, схильна до протиправної поведінки, то і ставлення ї̈ до судової влади буде відповідним. Така особа не довіряє собі, іншим і владі загалом та судовій владі зокрема. Отже, психологічний складник довіри до судової влади відображає позитивне сприйняття і відчуття щирості намірів органів судової влади, суддів і працівників апарату судової влади, відчуття безпеки. Саме на психічному рівні формується певний позитивний / негативний образ судової влади. Оскільки довіра виникає внаслідок справджування очікувань сторін, їньої готовності цим очікуванням відповідати і переконання в тому, що інша сторона поділяє відповідні норми та цінності, такі, як передбачуваність і надійність, то вона тісно «вплетена» у процес формування довіри.

По-четверте, довіра до судової влади має когнітивний складник, який виявляється в поінформованості та знаннях про діяльність судової влади. У розумінні когнітивного складника до уваги необхідно взяти міркування А. Іванова, який у когнітивному складникові розмежовує логіко-понятійні та ціннісно-мотиваційні аспекти. За допомогою мислення людина виходить за межі безпосередньо чуттєвого досвіду і проникає в сутнісні рівні об’єктів. Це сфера загальних понять, мисленєвих операцій і жорстких логічних доказів. Головною метою і регулятивом логіко-понятійної сфери $€$ істина. Ціннісно-мотиваційний аспект охоплює вищі мотиви діяльності та духовні ідеали особи. Метою і регулятивом буття цієї сфери свідомості є правда, справедливість, тобто цінності як форма узгодження предметної діяльності 3 нашими духовними цілями та сенсами. Суб'єктивно-особистісні та ціннісно-смислові компоненти психіки людини знаходяться немов би у знятому, латентному стані [13, с. 158-159].

Довіра до судової влади відображає ставлення, засноване на знаннях і впевненості в надійності, компетентності, сумлінності суддів, судових органів, посадовців, у їхній здатності ефективно виконувати функції із забезпечення належного судового процесу і правосуддя. У цьому сенсі когнітивний складник довіри до судової влади з боку громадськості й громадян залежить від поінформованості громадян про діяльність судової влади, від рівня правових знань, правового мислення, правової культури громадськості, окремих суб'єктів, які оцінюють їі діяльність.

Уваги заслуговують і міркування Л. Вітгенштейна, який довів, що знання і пізнання не зводяться до наук, а грунтуються на повсякденності, досвіді, життєвих знаннях і на гуманітарному знанні, їх «зразках науковості». Саме у цьому, на думку науковця, полягає довіра до суб'єкта як тут-буття і буття-в-світі, що $є$ фундаментальним підгрунтям пізнання. За такого підходу особливого значення набувають очевидності здорового глузду, практичні навички і вміння, різного роду впевненості, які йдуть від повсякденності та «життєвого світу». У своїй праці «Про достовірність» Л. Вітгенштейн обгрунтовує комплекс упевненостей, звичних орієнтацій, які передують і закладають підгрунтя 
знання «знизу» та не допускають свого обгрунтування [14, с. 146].

$\mathrm{У}$ розумінні природи довіри до судової влади, зокрема їі когнітивного складника та засад формування, до уваги необхідно взяти й міркування П. Бергера та Т. Лукмана у сфері соціології знання і соціального конструювання реальності. Науковці довели, що освіта передбачає обов'язкове засвоєння існуючої у культурі системи легітимації - пояснення і виправдання інститутів соціального порядку, різних його форм і ступенів. Легітимація має когнітивний i нормативний аспекти. Вона не лише приписує, як діяти, але й пояснює, чому явища і процеси є такими. Різні рівні легітимації охоплюють систему мовних об'єктивацій людського досвіду, теоретичні твердження і теорії, а також «символічні універсами». Останні $€$ «системами теоретичної традиції, які ввібрали різні галузі знань і включають інституційний порядок у всій його символічній цілісності... Символічний універсум розуміють як матрицю всіх соціально об'єктивованих і суб'єктивно реальних значень» [15, с. 157-158]. «... Символічний універсам інтегрує найрізноманітніші значення, що існують у повсякденному житті; класифікує феномени в певних категоріях ієрархії буття, визначаючи сферу соціального в цій ієрархії [15, с. 162-169].

Окрім того, важливо враховувати, що процес пізнання не вичерпується процесами відображення, а сам його результат - знання як образ того, що пізнається - часто досягається іншими за природою засобами в тісному взаємозв'язку з ними. «3 позицій філософії пізнання фундаментальними 3 них, разом із відображенням, $€$ такі: репрезентація як амбівалентний за своєю природою феномен одночасного уявлення, відображення об'єкта і його заміщення, конструювання (моделювання); конвенція - як обов'язкова подія комунікативної за природою та інтерсуб'єктивної діяль- ності пізнання; інтерпретація, яка $€$ не лише моментом пізнання і тлумаченням сенсів, але й способом буття» [16, c. 15-16].

Суб'єкт довіри до судової влади - це передусім суб'єкт, який інтерпретує, оскільки його існування і діяльність розгортаються не просто в об'єктивній дійсності, але й у світі створених ним образів, знаків і символічних форм, притаманних самій структурі людського життя. Інтерпретація виходить за межі операційно-методологічної діяльності 3 текстами у сферу фундаментальних основ пізнання і буття. Пізнання, оцінка, інтерпретація діяльності судової влади суб'єктом іманентно пов'язана зі смислами, гіпотезами, об'єднує в собі елементи буттєво-екзистенційного підходу, який передбачає як володіння внутрішньою свободою, так і вкоріненість у культурі, соціумі, а також власне когнітивні, гносеологічні та герменевтичні аспекти.

Довіра до судової влади значною мірою зумовлена рівнем повсякденного мислення громадськості, ऑї комунікації як із органами судової влади, так і між собою. Відтак, підвищення рівня довіри потребує оптимізації комунікативних процесів із судовою системою, іiі суб'єктами, гласності та відкритості судових процесів. Важливим $€$ розуміння процесу формування перцептивної установки як довіри і схильності до певних оцінок і діяльності - свого роду моделі очікуваних сенсорних подій, які $є$ проявом попереднього досвіду суб'єкта. Важлива особливість цих об'єктивних передумов і підстав довіри - їня соціокультурна зумовленість, яка породжується належністю, залученням суб'єкта до певного соціального буття, діяльності, комунікації, до культурно-історичних умов загалом. Суб'єктивна впевненість виникає на рівні сприйняття не лише як результату власних сенсорних процесів, апробації даних у діяльності, але i як прийняття на віру соціального 
досвіду загалом, «образів» та установок, представлених у культурі.

У контексті зазначеного заслуговує уваги досвід Канади в дослідженні громадської думки й довіри до судової влади. У спробах встановити наявність або відсутність загрози для суддівської незалежності, здатної вплинути на рівень громадської довіри, суди користувалися таким поняттям, як поміркована людина. Верховний Суд Канади дотримується позиції, що об’єктивний критерій визначення думки поміркованої людини повинен забезпечувати можливість визначення того, наскільки позитивно громадськість ставиться до питання суддівської незалежності [17]. Хоча цей підхід до правового аналізу є дуже корисним, він має очевидні обмеження. Одним із них є припущення щодо того, чи є поміркована людина інформованою. Друге обмеження випливає із припущення, що суд, який застосовує цей критерій, здатний зрозуміти умонастрій поміркованої людини. У реальній дійсності поміркована людина може виявитися непоінформованою або, якщо вона таки буде поінформованою, людина може не погодитися з тим, як саме ii умонастрій тлумачить суд [18]. Такі висновки пізніше вплинули на перегляд інформаційної політики судів і суддів у напрямі іï активізаціi. Стало очевидним, що довіра до судової влади залежить від поінформованості поміркованої людини щодо діяльності судової влади, судів і суддів. Саме публічна вичерпна інформація, відкритість і гласність діяльності судової влади значною мірою впливають на те, як поміркована особа ставитиметься до судової влади. Безумовно, поінформованість громадян автоматично не забезпечує підтримку і довіру громадськості до судів, але значно їй сприяє. У поєднанні з розумінням громадянами того, що діяльність судової влади спрямована на утвердження правосуддя в суспільстві, судова влада може розрахову- вати до довіру до неї у теперішній час i на певний кредит довіри в майбутньому.

У низці випадків когнітивний складник довіри до судової влади тісно пов'язаний із дієвим складником, який виявляється у свідомій, раціональній, добровільній діяльності, спрямованій на взаємодію із судовою владою стосовно підвищення іiі прозорості та підзвітності перед громадянським суспільством. Суб'єктами такої діяльності переважно є члени різних правозахисних організацій, громадські активісти. В окремих випадках вони залучаються до створення різних дорадчих і консультативних органів (Науково-методичних рад при судах, Громадської ради доброчесності тощо). Саме ця категорія громадян $€$ найбільш дотичною до діяльності органів судової влади і значною мірою впливає на формування громадської думки про судову владу та на рівень довіри до неї відповідно.

По-п'яте, природа довіри до судової влади тісно пов'язана із правомірністю і законністю. Правомірність у цьому сенсі $€$ тотожною легітимності, безпосередньо стосується правових меж діяльності судової влади, але нею не обмежується. У сучасних демократичних країнах судова влада - це складник конституційного ладу держав, які дотримуються принципу верховенства права. Зокрема КРЕС зауважує: «Якщо конституційний лад такої держави є легітимним, то засади судової влади, яка входить до нього, є такою ж легітимною і необхідною частиною демократичної держави, як і дві інші гілки влади» [19, с. 51]. Всі держави-члени мають певну форму конституції, яка різними способами визнається легітимною основою держави. Конституції усіх держав-членів визнають і закріплюють (безпосередньо чи опосередковано) роль судової влади як такої, що повинна підтримувати верховенство права та вирішувати справи із застосуванням законів, як це визначено 
законодавством і судовою практикою. Отже, той факт, що конституція створює судову владу для виконання цієї ролі, повинен водночас наділяти легітимністю судову владу загалом. Вирішуючи справи, кожен одноосібний суддя здійснює свої повноваження як представник судової влади. Відповідно сам факт, що судова влада $€$ складником конституційного ладу держави, надає легітимності не лише судовій владі загалом, але й кожному одноосібному судді.

Засадничими для легітимності $€$ незалежність та об'єктивність судової влади, на які звертають увагу як науковці, так і суди у своїх рішеннях. Зокрема, голова суду у відставці Суду провінціі Саскачеван (Канада) демонструє такий зв'язок конкретним прикладом, звернувшись до досвіду Верховного Суду Канади [20]: «Суддівська незалежність є гарантованою... і відіграє важливу роль у забезпеченні належного функціонування демократичної системи, передбаченої Конституцією Канади... Цей принцип, покликаний забезпечити довіру громадськості до судової системи і принципів верховенства права, був запроваджений із метою запобігання втручань з боку виконавчих та законодавчих органів у процес здійснення суддівських повноважень... Суддівська незалежність $€$ ефективним засобом забезпечення і підтримки впевненості суспільства в дієвості правосуддя, що саме є важливою передумовою формування відчуття поваги і прихильності щодо судової системи і принципів верховенства права... Отже, громадська довіра є гарантією ефективності нашої системи правосуддя, а також запровадження і реалізації принципу верховенства права ... Саме тому підтримка впевненості громадськості в належному відправленні правосуддя $€$ найсуттєвішим аспектом, який потребує належного врахування під час вирішення питань, пов'язаних із незалежним статусом суддів» [17].
В умовах наближення України до європейського правового простору та утвердження європейських стандартів правосуддя правова природа судової влади все більшою мірою виявляє свій зв'язок із визнанням правомірності іï діяльності міжнародними судовими (наприклад, Європейським судом з прав людини) і навіть квазісудовими (наприклад, Комітетом 3 прав людини) органами, а також певною мірою і судовими владами зарубіжних країн [21, с. 118]. Ця властивість судової влади набуває все більшого значення 3 огляду на активізацію взаємодії держав у міжнародних відносинах та $€$ важливою передумовою необхідності оформлення взаємних меж юрисдикцій органів судової влади в діяльності держав, проблемних питань визнання і виконання результатів судової діяльності (судових актів) однієї країни на території іншої. У розумінні правомірності, легітимності судової влади до уваги слід брати різні елементи легітимності судової влади, викладені у Висновку КРЕС № 18 (2015) «Позиція судової влади та їі відносини 3 іншими гілками державної влади в умовах сучасної демократії» [22] (м. Лондон, 16 жовтня 2015 року). У Висновку КРЕС, у розділі IV «Легітимність судової влади та іï елементів» виокремлено та схарактеризовано іï основні складники, а саме: 1) легітимність судової влади загалом; 2) конституційна або формальна легітимність одноосібних суддів; 3) функціональна легітимність одноосібних суддів.

Поряд із легітимністю судової влади загалом важливе значення має i конституційна чи формальна легітимність одноосібних суддів. В Україні, як і в інших демократичних країнах, для виконання суддівських функцій, закріплених конституцією, існує спеціальна процедура відбору й призначення суддів. Кожний суддя, призначений відповідно до конституції та інших правових норм, 
отримує свої конституційні повноваження і легітимність. Саме призначення відповідно до встановлених вимог і процедур надає одноосібним суддям відповідних повноважень. «Легітимність, надана окремому судді його призначенням відповідно до конституції та інших правових норм окремої держави, становить «конституційну або формальну легітимність окремого судді» [22]. Водночас у своїх висновках КРЕС акцентувала увагу на різних методах призначення суддів у державах-членах Ради Європи [19]. До них належать, наприклад, призначення радою суддів чи іншим незалежним органом, вибори в парламент і призначення виконавчою владою. Як відзначала КРЄС, кожна система має свої переваги й недоліки [23]. Призначення шляхом голосування в парламенті та, меншою мірою, призначення виконавчим органом можуть вважатися такими, що надають додаткову демократичну легітимність [24], хоча ці методи призначення несуть ризик політизації і залежності від інших гілок державної влади [19]. Попри відмінність у порядку призначення суддів у різних країнах залежно від національних особливостей КРЕС рекомендувала для запобігання різних ризиків, щоб «кожне рішення, пов'язане 3 призначенням чи кар'єрою судді, базувалося на об'єктивних критеріях, приймалося незалежним органом або підлягало гарантіям того, що воно прийматиметься тільки на основі цих критеріїв» [19]. Уваги заслуговують також інші висновки КРЕС. Зокрема стосовно прийняття рішень про призначення чи заохочення суддів KPЄC рекомендує, щоб у них брали участь незалежні органи влади, значну частину складу яких було обрано іншими суддями демократичним шляхом [19]. Важливою є і вказівка щодо гарантій одноосібних суддів.

Проявом правомірності та легітимності $€$ також функціональна легітимність одноосібних суддів, яка полягає насамперед у призначенні суддів відповідно до конституції і законів держави та виконанні суддями своєї конституційної ролі згідно із законодавством, здійсненні своїх повноважень у межах встановлених правових норм поведінки. Водночас легітимність одноосібних суддів цим не обмежується. КРЕС наголошує, що довіра громадськості до судової влади й повага до неї - гарантії ефективності судової системи [25]. Кожний суддя і судова влада загалом можуть досягти й підтримувати легітимність, лише завойовуючи та підтримуючи довіру громадськості. Цей інший вид легітимності визначають як «функціональну легітимність», яка пов'язується 3 низкою вимог щодо якості діяльності судової влади та дотримання високих етичних стандартів. У низці своїх висновків КРЕС обговорювала різні аспекти належної роботи суддів, різні способи підвищення якості та ефективності судових систем в інтересах суспільства. Саме тому КРEC прийняла висновки щодо різних способів досягнення функціональної легітимності, серед них, зокрема, є такі: початкова підготовка й підвищення кваліфікації суддів [26], справедливий судовий розгляд у розумні строки [23], роль національних суддів у забезпеченні ефективного застосування міжнародного та європейського права [27], судова рада на службі суспільства [28], якість судових рішень [29], ефективне виконання судових рішень [30], а також щодо інформаційних технологій [31], спеціалізації суддів [32], оцінювання суддів [33]. Важливим для досягнення функціональної легітимності $€$ належне виконання суддями своїх обов'язків у межах положень, викладених у дисциплінарних і процесуальних нормах держави у кримінальному праві. «Повноваження судді пов'язані з такими цінностями, як правда, законність, справедливість і свобода. Тому судді повинні виконувати свої обов'язки, дотримуючись 
найвищих стандартів професійної поведінки» [34]. Для функціональної легітимності та винесення правосудних рішень важливе значення має також ефективна комунікація і взаємодія судової влади та суддів із усіма сторонами судового процесу, зокрема 3 адвокатами [30; 32].

Правова природа довіри до судової влади, крім зазначеного вище, виявляється також у тому, що саме поняття «довіра до судової влади» унормоване в Законі України «Про відновлення довіри до судової влади в Україні» [35]. У преамбулі Закону наголошується про те, що: «цей Закон визначає правові та організаційні засади проведення спеціальної перевірки суддів судів загальної юрисдикції (далі - перевірка суддів) як тимчасового посиленого заходу 3 використанням існуючих процедур розгляду питань про притягнення суддів судів загальної юрисдикції до дисциплінарної відповідальності і звільнення з посади у зв'язку 3 порушенням присяги 3 метою підвищення авторитету судової влади України і довіри громадян до судової гілки влади, відновлення законності і справедливості». Крім того, згідно зі ст. 1 Закону визначається, що «метою перевірки суддів $є: 1)$ утвердження верховенства права в суспільстві, законності в діяльності судів; 2) відновлення довіри до судової влади в Україні; 3) з'ясування фактів, що свідчать про порушення суддями присяги, наявність підстав для притягнення суддів до дисциплінарної або кримінальної відповідальності; 4) утвердження в діяльності суддів принципів незалежності та неупередженості» [35].

Отже, законодавець під час визначення мети закону поєднав між собою верховенство права, законність, довіру до судової влади, незалежність, неупередженість, з одного боку, та порушення суддями присяги, наявність підстав для притягнення суддів до дисциплінарної або кримі- нальної відповідальності, 3 іншого боку. Відтак до змісту довіри до судової влади належить правовий складник, який втілюється в легітимності судової влади загалом, конституційній або формальній легітимності одноосібних суддів, функціональній легітимності одноосібних суддів, а також у нормативності. Попри те, що зміст поняття «довіра до судової влади» законодавцем не визначений, він пов'язується з авторитетом судової влади, їі здатністю забезпечувати верховенство права, законність, справедливість, незалежність, неупередженість, доступність правосуддя. Серед головних засобів, які забезпечують досягнення мети правосуддя в контексті предмету дослідження, слід виокремити рівність перед законом і судом, гласність і відкритість судового процесу, вимоги щодо етики та доброчесності судді, декларації родинних зв'язків судді.

Дослідження природи довіри до судової влади дає підстави зробити низку висновків та узагальнень. Довіра до судової влади - це складне, комплексне явище, котре має соціальну, етичну, культурно-цивілізаційну, психологічну, когнітивну, правову природу; відображає сприйняття і ставлення суспільства, соціальної групи, індивіда до діяльності органів судової влади, судових рішень; сформоване на основі оцінки ii діяльності й переконаності в істинності і правильності професійних, етичних, соціально-психологічних дій суддів, правосудності їхніх рішень та $€$ добровільним свідомо-позитивним ставленням, моральною або дієвою підтримкою судової влади нині та в майбутньому. Зазначені складники довіри до судової влади по-різному представлені у відмінних за суб'єктами видах довіри, тому під час формування напрямів і засобів відновлення суспільної довіри до судової влади в Україні необхідно різною мірою враховувати кожний із складників.

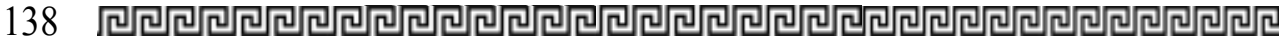


В якості комплексного явища довіра до судової влади має інструментальну, соціальну і власну цінність. Інструментальна цінність довіри до судової влади полягає в тому, що, маючи довіру до судової влади як складник правової культури, людина та суспільство вибудовують свою поведінку відповідно до встановлених правил і вимог, у разі необхідності в судовому порядку захищають свої права та інтереси, виконують судові рішення. Водночас особливості та відмінності національної правової системи і правової культури суспільства накладають відбиток як на форми нормативності, так і на процесуальний характер їі забезпечення. Соціальна цінність довіри до судової влади полягає в тому, що вона втілює загальне сприйняття і ставлення громадян та суспільства загалом, сприяє більш ефективній діяльності судової влади, ефективній комунікації між суспільством і судовою владою. Соціальна цінність довіри до судової влади визначається іiі здатністю спонукати осіб до судового вирішення правових конфліктів. Власна цінність довіри до судової влади полягає в тому, що довіра до судової влади виступає як критерій, показник і загальне мірило ефективності діяльності судової влади, правосудності їі рішень. Високий рівень довіри громадян і суспільства до судової влади надає їй простір для незалежності, прозорості, гласності, відкритості, здійснення заходів, спрямованих на підвищення ефективності, наближення до європейських стандартів судочинства.

Відновлення довіри до судової влади в Україні разом із визначенням природи і змісту довіри до судової влади потребує грунтовного дослідження і загальнотеоретичної характеристики суб'єкта / суб'єктів та об'єкта/об'єктів такої довіри, що і стане предметом подальших наукових досліджень.
Статтю присвячено визначенню природи і змісту довіри до судової влади в контексті світового досвіду як підтрунтя відновлення довіри до судової влади в Україні. Обтрунтовано, що довіра до судової влади це складне та комплексне явище, яке має соціальну, етичну, культурно-циивілізаційну, психологічну, когнітивну, правову природу, відображає сприйняття $i$ ставлення суспільства, соціальної групи, індивіда до діяльності органів судової влади, судових рішень, сформоване на основі оцінки ї діяльності та переконаності в істинності і правильності професійних, етичних, соціально-психологічних дій суддів, правосудності їхніх рішень, та $\epsilon$ добровільним свідомо-позитивним ставленням, моральною або дієвою підтримкою судової влади нині та в майбутньому. В якості комплексного явища довіра до судової влади має інструментальну, соціальну $i$ власну изіність. Інструментальна иінність довіри до судової влади полягае в тому, що, маючи довіру до судової влади як складник правової культури, людина та суспільство вибудовують свою поведінку відповідно до встановлених правил $i$ вимог, у разі необхідності в судовому порядку захищають свої права та інтереси, виконують судові рішення. Водночас особливості та відмінності національної правової системи, правової культури суспільства накладають відбиток як на форми нормативності, так і на процесуальний характер їі забезпечення. Соціальна цінність довіри до судової влади полягає в тому, що вона втілюе загальне сприйняття і ставлення громадян та суспільства загалом, сприяе більш ефективній діяльності судової влади, ефективній комунікації між суспільством $і$ судовою владою. Соціальна цүнність довіри до судової влади визначається ї̈ здатністю спонукати осіб до судового 
вирішення правових конфліктів. Власна цінність довіри до судової влади полягає в тому, що довіра до судової влади виступає як критерій, показник $i$ загальне мірило ефективності діяльності судовоі влади, правосудності ї рішень. Високий рівень довіри громадян $i$ суспільства до судової влади надає їй простір для незалежності, прозорості, гласності, відкритості, здійснення заходів, спрямованих на підвищення ефективності, наближення до європейських стандартів судочинства.

Ключові слова: довіра до судової влади, відновлення довіри, легітимність, судова влада, верховенство права.

Udovyka L., Novoselova V. The nature and content of trust in the judiciary in Ukraine through the prism of world experience

The article is devoted to defining the nature and content of trust in the judiciary in the context of world experience as a basis for restoring trust in the judiciary in Ukraine. It is substantiated that trust in the judiciary is a complex, complex phenomenon that has a social, ethical, cultural, civilizational, psychological, cognitive, legal nature, reflects the perception and attitude of society, social group, individual to the judiciary, court decisions, formed on the basis of assessment of its activity and conviction in the truth and correctness of professional, ethical, socio-psychological actions of judges, justice of their decisions, and is a voluntary consciously positive attitude, moral or effective support of the judiciary in the present and future. As a complex phenomenon, trust in the judiciary has instrumental, social and intrinsic value. The instrumental value of trust in the judiciary is that, having confidence in the judiciary as a component of legal culture, people, society build their behavior in accordance with established rules and requirements, if necessary, protect their rights and interests in court, enforce court decisions. At the same time, the peculiarities and differences of the national legal system and the legal culture of society leave an imprint both on the forms of normativeness and on the procedural nature of its provision. The social value of trust in the judiciary is that it embodies the general perception and attitude of citizens, society as a whole, promotes more efficient judiciary, effective communication between society and the judiciary. The social value of trust in the judiciary is determined by its ability to motivate individuals to resolve legal conflicts. The intrinsic value of trust in the judiciary is that trust in the judiciary acts as a criterion, indicator and general measure of the effectiveness of the judiciary, the justice of its decisions. The high level of trust of citizens and society in the judiciary gives it space for independence, transparency, transparency, openness, implementation of measures aimed at improving efficiency, approximation to European standards of justice.

Key words: trust in the judiciary, restoration of trust, legitimacy, judiciary, rule of law.

\section{Література}

1. Horodovenko V., Bondar O., Udovyka L. Jastice in the COVID-19 era Through the Prism of Judicial Power. Ius. Humani Law Jounal. 2021. Vol 10 (1). P. 51-72. URL: http: / / www.iushumani.org / index.php / iushumani/issue/view/11.

2. Центр Разумкова. "Довіра до інститутів суспільства та політиків, електоральні орієнтації громадян України (липень-cерпень 2021p.)». URL: https:// razumkov.org.ua/.../dovira-do-instytutiv...

3. StefanchukM., Hladun O., Stefanchuk R. Establishing trust in the court in Ukraine as a strategic task for Judicial Reform. Access to Justice in Eastern Europe. 2021. Vol. 3(11). URL:http:// ajee-journal.com / upload/attaches / att_1627905013.pdf 
4. Алексеев П. В., Панин А. В. Философия : учебник. Изд-е второе, перераб и доп. Москва: Проспект, 2015. 588 с.

5. Мальиев Г. В. Социальныце основания права. Москва: Норма, 2007. 800 с.

6. Яковлев А. М. Социальная структура общества и право: учеб. пособие. Москва: Норма, 2011. 368 с

7. Фукуяма Ф. Великий крах. Людська природа і відновлення соціального порядку / пер. $з$ англ. В. Дмитрика. Львів : Кальварія, 2005. 380 c.

8. Берхем B. Bступ до права та правової системи США. Київ : Издательство «Україна», 1999. 542 с.

9. Інструменти зміцнення довіри до суду в Україні. Аналітична записка. Центр економічної стратегії. 26 вересня 2019 p. URL: https://ces.org.ua/ wp-content / uploads / $2019 / 09 / \%$ D0\% A6\% D0\% $9 \mathrm{~F} \%$ D0\% $9 \mathrm{~F} \%$ D0\% AO-final$U A-2 . p d f$.

10. Рулан Н. Юридическая антропология: учебник для вузов / пер. с фр., отв. ред. В. С. Нерсесяни. Москва : НОРМА, 1999. $310 \mathrm{c}$.

11. Френк Н. В. Концепиия доверия в исследованиях Штомпки. СОЦИС, 2006. № 11. С. 10-18.

12. Скрипкина Т. П. Психология доверия: учеб. пособие. Москва : Изд. центр «Академия», 2000. 264 с.

13. Иванов А. В. Сознание и мышление. Москва: МГУ, 1994. 180 с.

14. Витгенштейн Л. О достоверности (фрагменты). Вопросы философии. 1984. № 8. C. 142-149.

15. Бергер П., Лукман Т. Социальное конструирование реальности. Трактат по социологии знания. Москва: «Медиум», 1995. 323 c.

16. Микешина Л. А. Философия познания. Проблемь эпистемологии гуманитарного знания. Изд. 2-е, дополн. Москва : Проспект, 2008. 374 с.

17. Лебел Дж. Параграф 176. URL: http: / / dspace.nbuv.gov.ua / bitstream / handle/123456789/14006/12-Senyuk.pdf.

18. Сенюк Дж. Т. Дж. Довіра до судів і суддів. Судова апеляиія. 2009. № 3 (16). C. 95-105.

19. Висновок № 1. Консультативної ради європейських суддів для Комітету міністрів Ради Європи про стандарти незалежності судових органів та незмінюваність суддів. Судова влада України. 2001. Офіщійний вебсайт. URL: https:// court.gov.ua/inshe/mss/.
20. Звіт ЄСПЛ за 2019 рік. Практика ЕСПЛ. Український аспект. URL: https: / / www.echr.com.ua / publication / zvit-yespl-za-2019-rik.

21. Воскобитова Л. А. Сущностнье характеристики судебной власти : монография. Ставрополь: Ставропольсервисшкола, 2003. 160 с.

22. Висновок № 18. Консультативної ради європейських суддів до уваги Коміmету міністрів Ради Європи про місие судової влади та ї̈ відносини з іншими гілками влади в сучасних демократіях. 2015. URL: https:// rm.coe.int/-18-2015/ 1680792013

23. Висновок № 6. Консультативної ради європейських суддів до уваги Коміmету Міністрів Ради Європи щодо справедливого суду в розумний строк та ролі судді в судових процесах з урахуванням альтернативних засобів вирішення спорів Судова влада України. 2004. Офіційний вебсайm. URL: https: / / court.gov.ua/ inshe / mss /.

24. Віттрек Ф. "Управління третьою владою”, вид-во "Мор Зібек” (Тюбінген), 2006. Він стверджує, що легітимність усіх чиновників у державі залежить в кінцевому рахунку від "волі народу" ( частина друга cmammi 20 Конституизіi Німеччини). Подібні положення можна знайти $і$ в конституиіях інших держав. Див., наприклад, статтю 3 Конституиії Франиії: "Основою будь-якого сувереніmету є народ”.

25. Висновок № 3. Консультативної ради європейських суддів до уваги Комітету Міністрів Ради Європи щзоо принщипів та правил, які регулюють професійну поведінку суддів, зокрема, питання етики, несумісної поведінки та безсторонності. Судова влада України. 2002. Офіційний вебсайт. URL: https: / / court.gov.ua/inshe/mss /.

26. Висновок № 4. Консультативної ради європейських суддів до уваги Комітету Міністрів Ради Європи щодо належної підготовки та підвищення кваліфікаціі суддів на національному та європейському рівні. Судова влада України. 2003. Офіційний вебсайт. URL: https: / / court.gov.ua/inshe/mss/.

27. Висновок № 16. Про відносини між суддями та адвокатами. Судова влада України. 2013. Офіційний вебсайт. URL: https://court.gov.ua/inshe/mss/.

28. Висновок № 10. Консультативної ради європейських суддів до уваги 
Комітету Міністрів Ради Європи щодо судової ради на службі суспільства. Судова влада України. 2007. Офіційний вебсайm. URL: https://court.gov.ua/ inshe/mss /.

29. Висновок № 11. Консультативної ради європейських суддів до уваги Комітету Міністрів Ради Європи щодо якості судових рішень. Судова влада України. 2008. Офіиійний вебсайm. URL: https:// court.gov.ua/inshe/mss /

30. Висновок № 16. Про відносини між суддями та адвокатами. Судова влада України. 2013. Офіційний вебсайт. URL: https: / / court.gov.ua/inshe/mss /.

31. Висновок № 14. Консультативноі ради європейських суддів «Судочинство та інформаційні технологї». Верховний суд України. 2011. Офіційний веб-сайт. URL: http: / / www.viaduk.net/clients / vsu/vsu.nsf/(documents) / 58F4A4DD76A ACFDOC2257D87004971A6.

32. Висновок № 15. Консультативної ради європейських суддів стосовно спеціалізації суддів. Офіційний вебсайт. Судова влада України. 2012. URL: https:// court.gov.ua/inshe/mss/.

33. Висновок № 17. Консультативної Ради Європейських суддів про оцінювання роботи суддів, якості правосуддя та повагу до незалежності судової влади. Судова влада України. 2014. Офіційний вебсайm. URL: https:// court.gov.ua/inshe/mss/.

34. Висновок № 3. Консультативної ради європейських суддів до уваги Комітету Міністрів Ради Європи щодо принципів та правил, які регулюють професійну поведінку суддів, зокрема, питання етики, несумісної поведінки та безсторонності. Судова влада України. 2002. Офіиійний вебсайm. URL: https:// court.gov.ua/inshe/mss/.

35. Про відновлення довіри до судової влади в Україні. Закон України від 08.04.2014 p. № 1188-VII. Відомості Верховної Ради (BВP). 2014. № 23. Cm. 870 . URL: https://zakon.rada.gov.ua/laws/ show / 1188-18. 